\title{
ELEMENTOS QUÍMICOS EM BIOLOGIA
}

\section{EFEITOS DA DEFICIÊNCIA E DO EXCESSO DE ELEMENTOS ESSENCIAIS}

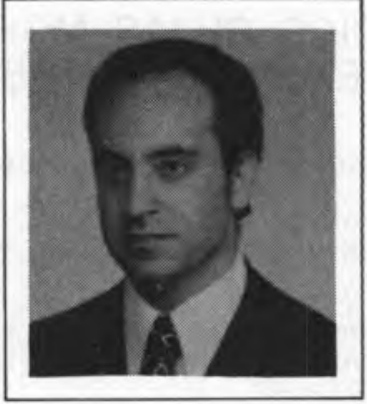

J.J.R. Fraústo da Silva Centro de Química Estrutural Complexo Interdisciplinar IST, Av. Rovisco Pais 1000 Lisboa - PORTUGAL

\section{Introdução}

No actual estádio de desenvolvimento dos conhecimentos sobre a utilização dos elementos químicos pelos sistemas biológicos sabe-se que apenas cerca de 25 elementos são essenciais à vida, dos quais 11 são requeridos em quantidades apreciáveis (macronutrientes) e os restantes em quantidades reduzidas, por vezes vestigiárias (micronutrientes).

$\mathrm{Da}$ análise da distribuição destes elementos no Quadro Periódico - Figura 1-pode tirar-se a conclusão de que a química da vida é, essencialmente, a química dos elementos leves, já qưe o número atómico dos elementos envolvidos é na quase totalidade dos casos, inferior a 30.

A razão da escolha destes elementos - e da rejeição de outros - deverá estar associada a um princípio de utilização económica de recursos, já que os elementos mais leves são também os mais abundantes e os mais «disponíveis» (sob o ponto de vista da maior facilidade na sua extracção das respectivas fontes), podendo, por outro lado, apresentar toda a variedade de comportamento químico dos diferentes grupos e sub-grupos do Quadro Periódico. Na verdade incluem representantes de quase todos eles, excluindo-se apenas os sub-grupos encimados pelo escândio, pelo titânio e pelos gases nobres (').

Os elementos rejeitados (tanto alguns «leves», como o alumínio, o títânio e o berílio, como os mais pesados
- cádmio, mercúrio, chumbo, por exemplo) são, em geral, prejudiciais aos sistemas biológicos, e alguns são mesmo fortemente tóxicos para diferentes formas de vida.

Haverá, porém, que dizer, também de uma forma geral, que todos os elementos químicos são tóxicos, mesmo os essenciais, dependendo da respectiva dose, do estado em que são ingeridos, da forma de ingestão e até da hora em que esta ocorre, variando o seu efeito de espécie para espécie.

Inversamente, alguns elementos reconhecidamente tóxicos podem ser utilizados com efeitos benéficos - relembremos os numerosos exemplos de medicamentos inorgânicos, desde os clássicos arsenicais aos modernos complexos da platina, empregados na terapia do cancro, ou ao simples carbonato de lítio, utilizado na terapia das doenças mania-depressivas.

Assim, o efeito fisiológico dos elementos químicos pode ser representado por curvas genéricas, que, no caso dos elementos essenciais apresentem um máximo, numa faixa de concentraçðes maior ou menor. Alguns casos concretos estudados confirmam o andamento previsto nas curvas teóricas. $\left({ }^{*}\right)$

No presente trabalho propomo-nos examinar em maior pormenor os efeitos da deficiência e do excesso dos elementos químicos considerados essenciais sobre o

(*) Para mais pormenores consulte-se referência (1) e ainda J.J.R. Fraústo da Silva, Bol. Soc. Port. Química, N. ${ }^{\circ} 1$ (2..$^{a}$ série), p. 2-13 (1979).

FIGURA 1 - DISTRIBUIÇÃo DOS ELEMENTOS ESSENCIAIS À VIDA

\begin{tabular}{|c|c|c|c|c|c|c|c|c|c|c|c|c|c|c|c|c|c|}
\hline IA & IIA & IIIA & IV & VA & VIA & VIIA & VIII & VIII & VIII & IB & IIB & IIIB & IVB & VB & VIB & VIIB & O \\
\hline $\mathrm{H} \star$ & & & & & & & & & & & & & & & & & $\mathrm{He}$ \\
\hline $\mathrm{Li}$ & $\mathrm{Be}$ & & & & & & & & & & & $\mathrm{B}$ म & $C \star$ & $N \star$ & $\mathrm{O} \star$ & $\mathrm{F}$ 出 & $\mathrm{Ne}$ \\
\hline $\mathrm{Na} \star$ & $\mathrm{Mg} \star$ & & & & i & & & & & & & AI & $\mathrm{Si}$ & $\mathrm{P} \star$ & $S \star$ & $\mathrm{CI} \star$ & $\mathrm{Ar}$ \\
\hline$K \star$ & $\mathrm{Ca} \star$ & $\mathrm{Sc}$ & $\mathrm{Ti}$ & $V_{\text {号 }}$ & $\mathrm{Cr}$ 名 & $\mathrm{Mn}$ 占 & $\mathrm{Fe}$ 하 & $\mathrm{Co}$ मr & $\mathrm{Ni}$ 々 & $\mathrm{Cu}$ ↔ & $\mathrm{Zn}$ 战 & $\mathrm{Ga}$ & $\mathrm{Ge}$ & As• & $\mathrm{Se} \not$ & $\mathrm{Br} \bullet$ & $\mathrm{Kr}$ \\
\hline $\mathrm{Rb}$ & $\mathrm{Sr}$ & $Y$ & $\mathrm{Zr}$ & $\mathrm{Nb}$ & Mo 占 & Tc & $\mathrm{Ru}$ & $\mathrm{Rh}$ & $\mathrm{Pd}$ & $\mathrm{Ag}$ & $\mathrm{Cd}$ & In & Sn• & $\mathrm{Sb}$ & $\mathrm{Te}$ & I 占 & $\mathrm{Xe}$ \\
\hline Cs & $\mathrm{Ba}$ & Ln & Hf & $\mathrm{Ta}$ & w & $\mathrm{Re}$ & Os & Ir & $\mathrm{Pt}$ & $\mathrm{Au}$ & $\mathrm{Hg}$ & $\mathrm{Tl}$ & $\mathrm{Pb}$ & $\mathrm{Bi}$ & Po & At & Rn \\
\hline Fr & $\mathrm{Ra}$ & Ac & Th & $\mathrm{Pa}$ & $\mathbf{U}$ & & & & & & & & & & & & \\
\hline
\end{tabular}

\ Elementos predominantes

น Oligoelementos que se julgam essenciais para a vida animal e vegetal

- Oligoelementos que se suspeita serem também essenciais 
desenvolvimento dos animais, em especial dos seres humanos, abrangendo no termo "desenvolvimento" o normal funcionamento dos seus processos metabólicos e, consequentemente, a manutenção do seu estado de "saúde».

Examinaremos, pois, sucessivamente, as funçð̃es biológicas que os diferentes elementos essenciais desempenham, os processos de manutenção das suas concentraçð̃es no organismo, a possível ocorrência de competiçð̃es entre os vários elementos e os sintomas associados às doenças provocadas pela carência ou pelo excesso de alguns deles, tanto quanto possivel relacionados com os mecanismos dos processos em que participam.

\section{Elementos biológicos e suas funções}

Apesar de alguns casos terem sido reconhecidos há longos anos (ferro, no século XVII e iodo, no século XIX), a história da descoberta da essencialidade de certos elementos químicos, designadamente os vestigiários, é relativamente recente e está intimamente associada ao desenvolvimento de métodos analíticos apropriados à detecção de micro-quantidades desses elementos, bem como à possibilidade de preparação de dietas alimentares isentas dos mesmos, a fim de se poder averiguar os efeitos da sua carência.

No Quadro I apresenta-se uma listagem dos elementos químicos vestigiários hoje considerados essenciais para a vida animal; dos 15 elementos referidos os primeiros 9 são essenciais também para os seres humanos, embora as necessidades específicas não estejam quantificadas rigorosamente em todos os casos. Os últimos 6 elementos tiveram a sua essencialidade provada em relação a animais de laboratório, mas não para seres humanos, ainda que para pelo menos um deles - o flúor - sejam conhecidos alguns efeitos benéficos em relação à incidência da cárie dentária, o que não implica que esta resulte necessariamente de uma deficiência nutritiva de tal elemento.

Uma análise cuidada das observaçð̃es do Quadro I, bem como da variedade de compostos e processos que a biologia utiliza, permite estabelecer, em termos gerais, as funçð̄es de cada um dos elementos biológicos; todavia, o facto de cada elemento poder assegurar mais do que uma função e o facto de existirem funçð̃es semelhantes asseguradas com a participação de elementos diferentes implica que cada elemento deverá ser finamente ajustado ou sintonizado para cada função específica, certamente através da sua combinação com espécies químicas adequadas.

Assim, o cálcio pode ser usado como formador de estruturas, combinado com fosfato ou carbonato, mas pode também actuar como desencadeador de certos fenómenos, como a contracção muscular, associando-se às proteínas envolvidas no processo. Em contraposição, pode citar-se o caso do ferro, manganês e cobre, constituintes de três diferentes superóxido dismutases, enzimas que catalisam a dismutação do superóxido em oxigénio e peróxido de hidrogénio, uma mesma função assegurada por elementos diferentes, provavelmente para operar em circunstâncias também diferentes ( ${ }^{2}$.

Sem prejuizo deste aspecto, que é importante -o da modulação das propriedades de cada elemento essencial através da sua combinação com outra espécie química adequada - podem esquematizar-se as funçð̋es principais dos elementos biológicos tal como se apresenta no Quadro II.
Quadro 1

Elementos químicos essenciais para seres humanos e para animais (micronutrientes)

\begin{tabular}{lll}
\hline Elemento & $\begin{array}{l}\text { Descoberta da } \\
\text { essencialidade }\end{array}$ & Observaçōes \\
\hline Ferro & Século XVII & $\begin{array}{l}\text { Componente da hemoglobina, mioglobi- } \\
\text { na, citocromos e enzimas para reaçōes } \\
\text { redox }\end{array}$ \\
Iodo & 1850 & $\begin{array}{l}\text { Necessário para a sintese das hormonas } \\
\text { da tiróide }\end{array}$ \\
Cobre & 1928 & $\begin{array}{l}\text { Componente de enzimas para reacçōes } \\
\text { redox; envolvido na mobilização de ferro } \\
\text { para sintese da hemoglobina }\end{array}$
\end{tabular}

Manganês $1931 \quad$ Envolvido na activação de enzimas e na formação de ossos e cartilagens; necessário para a fertilidade normal do gado

Zinco 1934 Associado à insulina e componente de mais de 90 enzimas - catálise ácido-base, sintese do DNA e RNA, etc.

Cobalto 1935 Componente da vitamina $\mathrm{B}_{12}$ necessária à hematopoiese

Molibdénio 1953 Componente de enzimas (xantina-oxidase)

Selénio 1957 Componente de enzimas (glutationa peroxidase e outras); impedimento à peroxidação dos lípidos associado à vitamina $\mathrm{E}$

Crómio 1959 Envolvido no metabolismo da glucose; componente do chamado «factor de tolerância à glucose" "

Estanho $1970 \quad$ Essencial para o crescimento normal de ratos

Vanádio $1971 \quad$ Idem dos ratos e pintos; envolvido no mecanismo da $(\mathrm{Na}+\mathrm{K})$-ATPase

Flúor 1972 Essencial para o crescimento normal de ratos; efeito preventivo da cárie dentária

Silício 1972 Essencial para o desenvolvimento normal de mucosas e ossos de ratos e pintos. Envolvido no mecanismo de formação de ossos

Niquel $\quad 1974 \quad$ Essencial para o crescimento e formação de glóbulos vermelhos de ratos

Arsénio 1975 Essencial para o desenvolvimento de ratos e cobaias

Entre estas funçð̃es predominam as relativas à catálise enzimática de reacçס̋es de vários tipos, à formação de moléculas biológicas e de estruturas de suporte (ossos, conchas, etc.) e à condução iónica, manutenção do equilibrio hídrico e da pressão osmótica, para além de outras mais específicas das quais se dão apenas alguns exemplos no Quadro II.

Os micronutrientes estão, com seria de esperar, ligados ao primeiro grupo de funçðes, ainda que não exclusivamente; assim, o silício $\left({ }^{*}\right)$ pode ter funçð̌es estruturais, promovendo o entrosamento das fibras de

(*) $\mathrm{Na}$ realidade, o silicio não se pode considerar propriamente como micronutriente pois o teor total deste elemento no corpo humano é quase igual ao do magnésio, que figura ente os elemèntos predominantes (ver Quadro IX). 


\section{Quadro II}

Funçōes principais dos elementos quimicos biológicos (macro e micronutrientes)

\begin{tabular}{|c|c|c|}
\hline Funçōes & $\begin{array}{l}\text { Elementos } \\
\text { quimicos }\end{array}$ & $\begin{array}{c}\text { Processo químico } \\
\text { e observaçðes }\end{array}$ \\
\hline $\begin{array}{l}\text { Funçōes electro- } \\
\text { químicas; contro- } \\
\text { le osmótico; } \\
\text { transmissão } \\
\text { de mensagens }\end{array}$ & $\begin{array}{c}\mathrm{Na}, \mathrm{K}, \mathrm{Cl} \\
(\mathrm{Mg}),(\mathrm{Ca}),\left(\mathrm{SO}^{2}\right.\end{array}$ & $\begin{array}{l}\text { Em solução aquosa, na forma de } \\
\text { )iôs livres; transporte de carga } \\
\text { (correntes iónicas) }\end{array}$ \\
\hline
\end{tabular}

Formação de es- $\quad \mathrm{H}, \mathrm{O}, \mathrm{C}, \mathrm{N}, \mathrm{P}, \mathrm{S}$, Formação de compostos orgânitruturas (molécu- F, Ca, $\mathrm{Si},(\mathrm{Mg})$ cos ou sais pouco solúveis, como las biológicas, es- o fosfato e carbonato de cálcio. truturas de su- "Cross-linking» nos tecidos conporte) juntivos

Catálise ácida $\quad \mathrm{Zn}, \mathrm{Ni}(?) \quad$ Em enzimas (cerca de 100 conhecidas; Ni na urease); reacçð̋es de hidrólise. Degradação de alimentos.

Catálise de reac- $\mathrm{Fe}, \mathrm{Cu}, \mathrm{Mn}, \mathrm{Mo}, \mathrm{Em}$ proteinas ou enzimas; reacçôes redox Se, (Co?), (V?) ç̋es com o oxigénio e seus produtos de redução, inibição da peroxidação de lípidos $(\mathrm{Se})$

Outras funçס̄es

(exemplos):

Sintese de DNA

e RNA

$\mathrm{Zn}, \mathrm{Mg}, \mathrm{Ca}$ Catálise de reacção de sintese, produção de energia

Controle hor- $\quad$ I, Ca Hormonas da tiróide (I), rompi-

monal mento de vesiculas $(\mathrm{Ca})$

colagéneo $\left({ }^{3}\right)$ ou formando esqueletos externos de sílica, e o zinco parece estabilizar as estruturas secundária e terciária do RNA. Do mesmo modo, alguns macronutrientes podem ter funçðes catalíticas; o magnésio, por exemplo, é um activador de várias enzimas.

Posto o problema nestes termos, surgem naturalmente dois focos de interesse neste domínio do estudo das funçð̃es dos elementos químicos em biologia: o dos processos e mecanismos da captura e rejeição dos diferentes elementos pelos sistemas biológicos e o dos modos de armazenamento e redistribuição desses elementos em organismos evoluídos.

No presente trabalho não nos ocuparemos das questōes relacionadas com a captura, que já noutra ocasião abordámos ( 1 ), focando a nossa atenção sobre o segundo tipo de questðes, relativas ao armazenamento e mobilização dos depósitos eventualmente constituídos nos organismos vivos, particularmente nos animais.

\section{Formas de armazenamento e de redistribuição dos elementos químicos em sistemas biológicos}

De um modo geral, armazenamento implica acumulação e acumulação pressupōe uma condição ligada ou a manutenção de um local de concentração mais elevada, através de processos de transporte activo que requerem o dispêndio de energia. Em qualquer dos casos, como também no da rejeição de elementos por um determinado organismo ou por um compartimento desse organismo, deverão estar envolvidos ligandos biológicos selectivos em relação a esses elementos e, em alguns casos, também artifícios ou dispositivos de base cinética. Isto é, na análise destes processos haverá que ter em conta argumentos de natureza termodinâmica (estabilidade de complexos) e argumentos de natureza cinética.

$\mathrm{O}$ armazenamento pode ser intracelular ou extracelular; no $1 .^{\circ}$ caso pode ser assegurado por acumulação contra o gradiente de concentração ou por combinação química num estado ligado, mas no caso de ser extracelular só se pode verificar a segunda hipótese. Deve ainda notar-se que o armazenamento intracelular se pode dar no interior de compartimentos de célula-organelas ou vesículas.

No que se refere ao armazenamento extracelular, é curioso observar que existe, em muitos casos, uma curiosa relação, certamente evolucionista e, como sempre, determinada por princípios de utilização económica de recursos e optimização funcional, entre armazenamento e formação de estruturas de suporte, como o esqueleto dos mamíferos que é, simultaneamente, um depósito de fosfato de cálcio, cujos componentes podem ser mobilizados. Aliás, as próprias macromoléculas biológicas constituem formas de armazenamento - de carbono e hidrogénio no caso das gorduras e polisacarídeos e de carbono e azoto no caso das proteinas. Esta relação, todavia, não é absoluta, pois podem existir depósitos móveis (caso do oxigénio, ligado à hemoglobina).

De qualquer forma, existe uma diferença importante entre o armazenamento de compostos orgânicos e o de elementos «minerais", na forma de compostos inorgânicos ou complexos. No primeiro caso, os processos de armazenamento e de mobilização são conseguidos através de reacçð̄es de polimerização e de despolimerização, catalisadas por determinadas enzimas; no segundo caso existe em geral um reagente «solubilizador" que compete pelo elemento armazenado e o transporta até ao local onde é requerido, onde é deslocado para uma sede activa, novamente por um processo de competição (que pode envolver reacçð̄es de oxidação-redução).

O processo põe em jogo parâmetros de natureza termodinâmica e cinética e assemelha-se naturalmente ao esquema clássico da marcha geral da análise, no qual a separação dos diferentes iðes é assegurada através de uma graduação de produtos de solubilidade de sais e de constantes de estabilidade de diferentes complexos $\left({ }^{4}\right)$.

O Quadro III dá uma ideia dos precipitantes e complexantes que podem ser utilizados para o efeito e, na realidade, a biologia utiliza ligandos do tipo indicado, conforme se pode verificar no conjunto de exemplos que se apresenta no Quadro IV.

É evidente que os fenómenos de armazenamento e mobilização de depósitos estão ligados à necessidade de manutenção de um nível óptimo de concentração dos vários elementos, de tal modo que os sistemas onde se verifiquem não sofram por efeito de deficiências ou excesso na ingestão dos mesmos. Trata-se portanto de um mecanismo regulador, podendo também nestes casos falar-se em homeostasia ou, para manter a analogia com a linguagem dos químicos analistas, de um processo de "tamponização" da concentração dos elementos químicos essenciais.

Esquematicamente, pode representar-se esse mecanismo através de um diagrama simples ilustrando o equilíbrio (químico) entre as formas ligadas e as formas móveis 


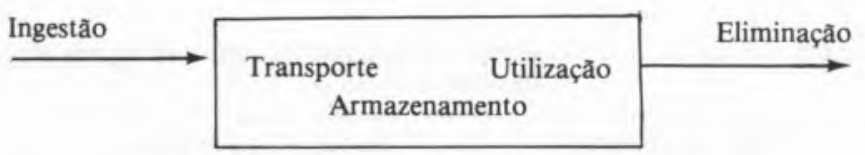

suor. Se esses elementos não forem repostos podem surgir sintomas tais como cãibras, cefaléia, entorpecimento mental e até sobrevir um estado de choque.

$\mathrm{O}$ assunto é bem conhecido e sobre ele não nos alargaremos, limitando-nos a assinalar a diferença no

Quadro III

Exemplos de ligandos usados para a precipitação, solubilização e deteç̧ão final de alguns elementos essenciais, no esquema geral da análise

\begin{tabular}{|c|c|c|c|}
\hline Elemento & Forma precipitada & Solubilizador & Forma de detecção química \\
\hline Cálcio & Carbonato, Fosfato, oxalato & Oxianião orgânico (p. ex. polifosfato, citrato) & Carboxilatos \\
\hline Ferro & Hidróxido & Fenolato & $\begin{array}{l}\text { Aminas aromáticas } \\
\left(\mathrm{Fe}^{2+}\right) \text {, sulfuretos }\end{array}$ \\
\hline Cobre & Sulfureto & Aminas & Aminas/sulfuretos \\
\hline Zinco & Sulfureto & Aminas & Aminas/sulfuretos \\
\hline Sódio e potássio & Nenhuma & Desnecessário & Nenhuma adequada \\
\hline
\end{tabular}

Adaptado com modificaçðes de R.J.P. Williams: Chemistry in Britain, 15, 506 (1979).

Quadro IV

Formas de armazenamento e de transporte de alguns elementos essenciais

\begin{tabular}{|c|c|c|c|}
\hline Elemento & Forma de armazenamento & Forma de transporte & Sede final (exemplos) \\
\hline Cálcio & Nos ossos: fosfato de cálcio & Fosfoproteina & Lisosima ( 2 carboxilatos) \\
\hline Ferro & $\begin{array}{l}\text { Ferritina (partículas de } \mathrm{Fe}_{2} \mathrm{O}_{3} \text { asso- } \\
\text { ciadas a proteina) }\end{array}$ & $\begin{array}{l}\text { Transferrina (proteina com grupos fenólicos } \\
\text { de tirosina) }\end{array}$ & Heme ou grupos tiolato \\
\hline Cobre & $\begin{array}{l}\text { No figado: proteinas com grupos } \\
\text { tiolato }\end{array}$ & $\begin{array}{l}\text { Ceruloplasmina (?) e Cu-albumina (4 doadores } \\
\text { nitrogenados) }\end{array}$ & $\begin{array}{l}\mathrm{Cu} / \mathrm{Zn}-\text { superóxido dismutase (3 } \\
\text { imidazol) }\end{array}$ \\
\hline Zinco & $\begin{array}{l}\text { Na pele e ossos: proteínas com } \\
\text { grupos tiolato }\end{array}$ & $\begin{array}{l}\text { Zn-albumina (provavelmente } 3 \text { ou } 4 \\
\text { doadores } \mathrm{N} / \mathrm{S} \text { ). }\end{array}$ & $\begin{array}{l}\text { Álcobl de hidrogenase ( } 4 \text { grupos-Sh } \\
\text { de cisteina ou } 3 \text { cisteina }+1 \text { imida- } \\
\left.\text { zol }+1 \mathrm{H}_{2} \mathrm{O}\right)\end{array}$ \\
\hline Sódio e potássio & Nenhuma & IØes livres & Nenhuma \\
\hline
\end{tabular}

É claro que, nos casos em que o elemento é armazenado intracelularmente sob uma forma concentrada e libertado por rompimento das vesículas em que se encontra ou por abertura de canais adequados, dá-se um súbito aumento de concentração, e esse será um processo conveniente para desencadear fenómenos rápidos, como é o caso da contracção muscular ou da transmissão de mensagens pelos nervos. Nestes casos não faz sentido falar de tamponização (ao nível local), o que não significa que a concentração (extracelular) do elemento considerado não seja também regulada globalmente dentro de limites estreitos por processos análogos ao descrito acima.

Noutros casos (sódio, potássio) não há propriamente um processo de armazenamento, mas a concentração total destes elementos também é mantida constante, pelo que as quantidades absorvidas dos mesmos terão de ser praticamente iguais às eliminadas.

Deste modo os riscos de ingestão em excesso são baixos, mas o risco proveniente de ingestão em quantidades inferiores às eliminadas é elevado, podendo ocasionar perturbaçð̃es mais ou menos graves em prazo curto. É o que acontece quando, por efeito de um esforço muito intenso e prolongado, se perde uma quantidade considerável de cloreto de sódio através do processo de regulação, que não envolve a mobilização de um depósito, mas sim, apenas, a variação das quantidades eliminadas de acordo com as quantidades ingeridas, para o que existe um órgão próprio - os rins.

Como é evidente, no caso de haver armazenamento, os requisitos diários são apenas os necessários para manter os depósitos abastecidos e os efeitos de ingestão insuficiente dos elementos correspondentes não se reflectem a tão curto prazo, já que esses depósitos podem ser mobilizados para suprir as deficiências. A médio ou a longo prazo, porém, mantendo-se a insuficiência de suprimento do elemento ou elementos requeridos, manifestar-se-ão perturbaçð̃es diversas, correspondentes ao deficiente funcionamento dos processos bioquímicos em que esses elementos intervêm directa ou indirectamente.

O problema do excesso de ingestão é aparentemente mais complexo, na medida em que não só os mecanismos reguladores podem não ter a capacidade necessária ou não reagir com a velocidade adequada, como também poderão ocorrer, com maior probabilidade, reaç̧ð̄es de competição com outros elementos essenciais ou com moléculas biológicas que normalmente não seriam afectadas. O mesmo acontece com os elementos não essenciais incluindo os considerados tóxicos, 'podendo prever-se teoricamente uma série de mecanismos para as interacçð̃es mais prováveis ${ }^{(5,6)}$. 
Sem preocupaçð̃es de exaustão do assunto, apresentam-se no Quadro V algumas espécies que podem competir com diversos elementos essenciais, substituindo-os nas suas sedes próprias ou contaminando-os nas suas sedes próprias ou contaminando-as em maior ou menor grau.

A possibilidade de substituição de um elemento essencial por outro elemento, essencial ou não, é assim um aspecto a ter em conta, quer em processos naturais quer em actuaçð̌es deliberadas, o que tem consequências importantes para a interpretação dos fenómenos da toxicidade ou da acção de determinadas substâncias inorgânicas usadas como drogas medicamentosas.

Adiante retomaremos este assunto de um ponto de vista mais geral, limitando-nos, para finalizar a presente secção, a comentar resumidamente três exemplos ilustrativos dos processos de armazenamento e de mobilização dos depósitos de elementos essenciais: os casos do ferro, do cálcio e do zinco no corpo humano.

$\mathrm{O}$ ferro é absorvido principalmente no duodeno por processos ainda não totalmente esclarecidos $\left({ }^{7}\right)$, provavelmente na forma de quelatos de $\mathrm{Fe}(\mathrm{II})$.

Esses quelatos cedem o ferro à apoferritina sendo o metal oxidado prévia ou simultaneamente a $\mathrm{Fe}(\mathrm{III})$. A ferritina formada é o principal depósito de ferro no organismo e é armazenada em órgãos, como o fígado, o baço e a medula óssea. Como já antes se referiu, a ferritina é constituída por micelas de $\mathrm{Fe}_{2} \mathrm{O}_{3}$, ou, mais provavelmente, uma associação de hidroxido e fosfato férrico, com a composição aproximada $\mathrm{FeO}\left(\mathrm{H}_{2} \mathrm{PO}_{3}\right)$. $8 \mathrm{Fe}(\mathrm{OH})_{3},\left({ }^{8}\right)$, inseridas num envólucro de proteína.
Quadro V

Exemplos de elementos ou espécies que podem substituir alguns elementos essenciais

\begin{tabular}{ll}
\multicolumn{1}{c}{ Elemento essencial } & \multicolumn{1}{c}{ Espécies interferentes } \\
\hline Cálcio & $\begin{array}{l}\text { Estrôncio, Cádmio, Chumbo, Lantani- } \\
\text { dos e Actinidos } \\
\text { Cobre }\end{array}$ \\
Ferro & Crómo, Cádmio, Manganês, Aluminio \\
Fósforo (fosfato) & Carbonato, Vanadato (?), Arsenato (?) \\
Vanádio (em vanadócitos) & Nióbio, Manganês (?) \\
Zinco & Cobre, Cádmio, Mercúrio, Chumbo \\
\hline
\end{tabular}

ligaçð̃es transitórias, e este é um artifício adicional necessário para assegurar especificidade num processo biológico particularmente delicado. $\mathrm{O}$ assunto é objecto de investigação corrente $\left(^{9-11}\right)$ e sobre ele não nos alongaremos.

Como o período de vida dos glóbulos vermelhos é de cerca de 120 dias, o ferro correspondente é re-utilizado, pelo que as necessidades de ingestão diária do elemento são reduzidas e correspondentes apenas às perdas (maiores na mulher do que no homem, devido ao seu ciclo menstrual).

Esquematicamente, pode representar-se o processo do seguinte modo:

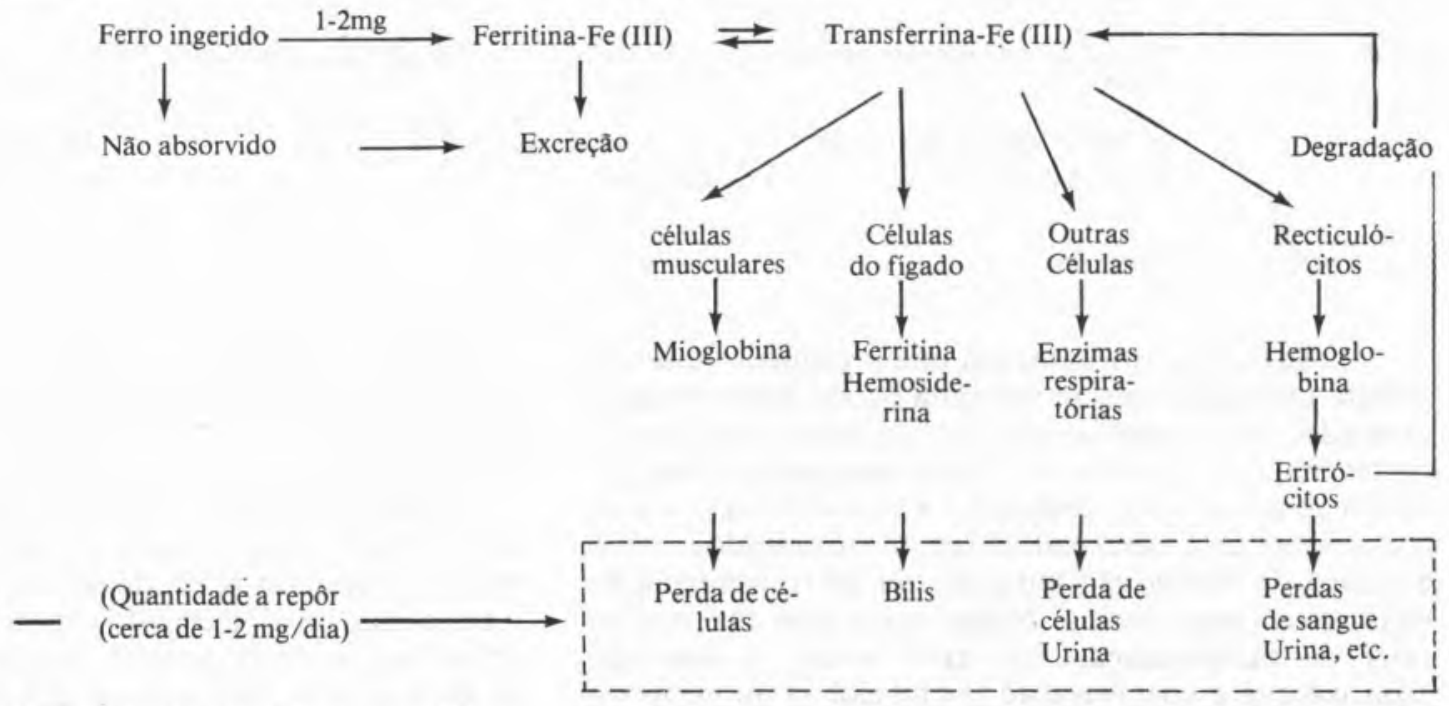

A mobilização do ferro da ferritina envolve a redução ao estado de $\mathrm{Fe}$ (II) seguida de nova oxidação a ferro (III) e a associação a uma proteína contendo grupos fenólicos (da tirosina), a transferrina (com 2 átomos de $\mathrm{Fe}(\mathrm{III})$ por molécula), a qual transporta o ferro aos locais onde é necessário: aos recticulócitos onde é sintetizada a hemoglobima e a outras células onde é cedido a diversas proteínas ou enzimas que o requerem. Embora as ligaçסes $\mathrm{Fe}$ (III) - transferrina sejam reversíveis, a estabilidade do complexo é elevada; o processo de transferência do ferro poderá assim necessitar, uma vez mais, uma redução prévia a $\mathrm{Fe}(\mathrm{II})$ - e esse é certamente o caso na formação da hemoglobina que contém o metal nesse estado.

Ao que parece, a transferrina é reconhecida especificamente pelos recticulócitos, formando com eles
O cálcio é absorvido através do intestino delgado, num processo favorecido pela vitamina $\mathrm{D}$, que parece promover a formação de uma fosfo-proteína complexante deste metal ${ }^{12}$ (constante de estabilidade da ordem de $\left.10^{5} \mathrm{M}^{-1}\right)$. Esta ou análoga proteína transporta o cálcio aos diferentes locais em que é requerido e em especial aos osteoblastos (células de formação dos ossos) onde é acumulado em organelas juntamente com o ião fosfato.

Excedido o produto de solubilidade do fosfato de cálcio este precipita e forma grânulos que são expelidos para fora da célula e depositados numa matriz de colagéneo, bem como muco-polisacarídeos e mucoproteínas (constitindo a chamada "substância fundamental») onde lentamente cristalizam formando os 
cristalículos de hidroxiapatite constitutivos dos ossos. A presença de silício pode ter um papel importante neste processo $\left({ }^{14}\right)$, que é ainda bastante mal conhecido $\left({ }^{15}\right)$.

Deve salientar-se que o osso é um tecido vivo, em processo contínuo de formação e reabsorção regulado pela acção das hormonas da paratiróide e pela vitamina D. Naturalmente as camadas mais jovens encontram-se em contacto com o líquido extracelular (do qual a substância fundamental é um prolongamento directo), pelo que se poderão dar trocas iónicas que levam a substituições de ið̃es na estrutura superficial. Assim, o estrôncio, o chumbo, o zinco, o sódio e outros catiōes podem substituir o cálcio, e o flúor, o citrato e o carbonato podem substituir o fosfato. As camadas internas não são facilmente permutáveis e exigem, provavelmente, a degradação da substância óssea para sua mobilização; pode, assim, falar-se de um depósito lábil em equilíbrio com o líquido extracelular e de um depósito mais fixo, mobilizável apenas em condiçōes de carência mais críticas através da acção das hormonas paratiróides. O mecanismo da mobilização é desconhecido, mas o ácido cítrico, que forma complexos solúveis de cálcio, pode ter um papel importante no mesmo.

Esquematicamente o processo global pode ser representado do seguinte modo

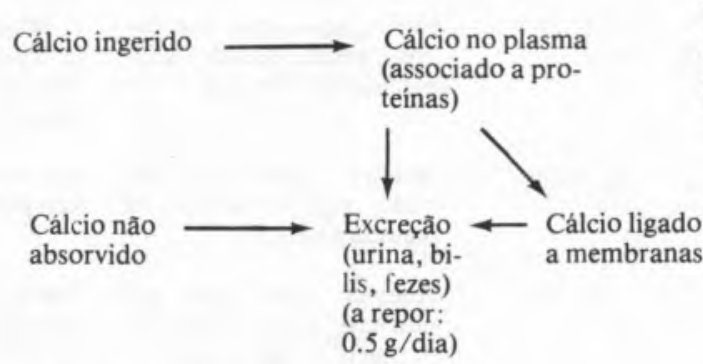

\author{
Osso $(95 \%$ de todo o \\ cálcio)
}

$\underset{\begin{array}{l}\text { Hormonas da } \\ \text { paratiróide }\end{array}}{\stackrel{\text { Vitamina D }}{\rightleftarrows}} \begin{aligned} & \text { Osso (95\% de todo o } \\ & \text { cálcio })\end{aligned}$

(tiolato) e azoto, podendo ligar-se igualmente a diversos aminoácidos entre os quais a histidina. Nesta forma é levado aos tecidos e órgãos utilizadores e aí é cedido a novos ligandos, mas a velocidade de formação dos depósitos e da sua mobilização varia de acordo com aqueles, sendo lenta para tecidos epiteliais, ósseos e do sistema nervoso central, média para tecidos musculares e eritrócitos e rápida para órgãos como o pâncreas, fígado, rim, baço e glândulas sexuais masculinas.

Em caso de deficiência a mobilização destes depósitos segue a mesma ordem; pâncreas, fígado, etc. em primeiro lugar, tecidos epiteliais e ósseos em último lugar. Esta será provavelmente a razão pela qual a deficiência de zinco se reflecte a curto prazo na interrupção do crescimento e em último na forma de lesø̃es epiteliais e ósseas, mas não existe evidência experimental suficiente para fundamentar a afirmação.

Esquematicamente, o processo pode representar-se do seguinte modo: $\mathrm{Zn}$-albumina,

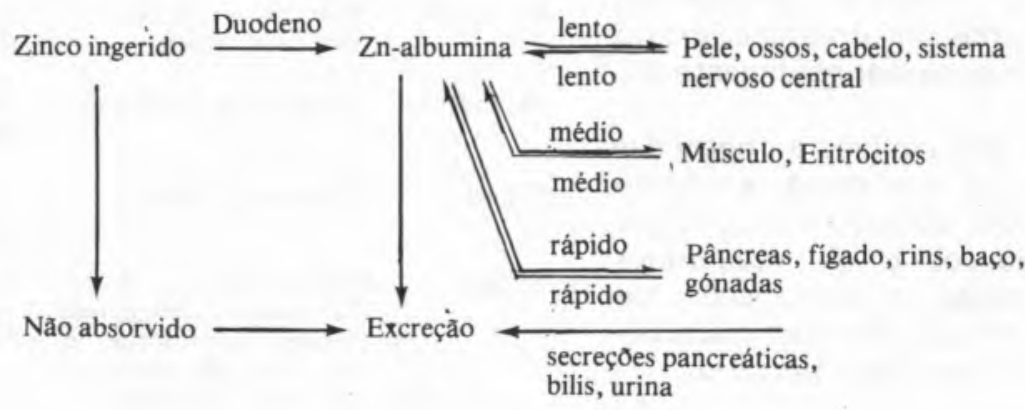

As necessidades diárias no adulto correspondem às perdas e são da ordem de $3 \mathrm{mg} /$ dia, para um depósito total relativamente reduzido de cerca de $2 \mathrm{~g}$. Uma dieta alimentar normal contém $10-15 \mathrm{mg}$ de zinco dos quais cerca de $40 \%$ são absorvidos, pelo que um estado de deficiência deste elemento não é de esperar. Todavia, a presença de antagonistas como o fitato e o cálcio pode reduzir substancialmente as quantidades efectivamente absorvidas, pelo que não só em países menos desenvolvidos como em países altamente desenvolvidos, a ocorrência da deficiência de zinco não é fenómeno invulgar. 
O aspecto porventura mais grave na deficiência deste elemento deriva dos baixos valores das concentraçð̃es em jogo e da fácil substituição deste elemento por outros nas suas sedes funcionais (o ião $\mathrm{Zn}^{2+}$ não é muito específico nos seus requisitos e foma complexos de estabilidade da ordem de ou inferior às dos complexos dos elementos de transição mais correntes). Nestas condiçøes, aos efeitos da carência podem somar-se efeitos de substituição, que, em certos mecanismos envolvendo enzimas de zinco (caso das DNA e RNA-polimerases), podem ter consequências desastrosas (efeitos teratogénicos, por exemplo).

Note-se que a acumulação de zinco no pâncreas pode ter um significado particular. $\mathrm{Na}$ verdade é nesse órgão que está armazenada a insulina (nas chamadas células - $\beta$ ) e a libertação desta pode ser medida por aquele metal através de um processo de competição do seguinte tipo:

[Célula $\beta$-insulina-zinco] + histidina (ou outro ligando)

$$
\text { [Zinco-histidina] }+ \text { insulina }+ \text { célula } \beta
$$

\section{Efeitos da deficiência e do excesso de elementos essen- ciais}

Após as consideraçð̃es anteriores, examinemos agora, em maior pormenor, alguns aspectos relacionados com o efeito das deficiências ou excessos dos elementos essenciais na dieta alimentar dos animais, em particular do homem.

No Quadro VI resumem-se algumas perturbaçð̃es ou doenças mais importantes associadas à carência ou excesso de elementos essenciais, motivadas por desequilíbrios na dieta alimentar ou por outras razōes que comentaremos adiante.

Constatadas as relaç̃̃es existentes entré carências, excessos e perturbaçð̃es ou estados patológicos, surgem várias ordens de problemas de diferente natureza cuja análise se torna particularmente importante, tanto do ponto de vista clínico-humanitário como do ponto de vista económico. $\mathrm{Na}$ verdade, muitas das doenças referidas manifestam-se em animais - gado ruminante, ovino e porcino - e causam prejuízos avultados aos pecuaristas, para além de, talvez mais frequentemente, benefícios inferiores aos possíveis por desconhecimento das causas de menor qualidade ou menor rendimento dos seus rebanhos.

Convém assim examinar, por um lado a origem das deficiências (ou dos excessos) e, por outro, a relação entre o papel de cada elemento químico essencial nos diferentes processos bioquímicos e os mecanismos através dos quais são induzidas as perturbaçøes ou estados patológicos, isto é, a relação elemento essencial-processo bioquímico afectado-sintomas observados.

A origem das deficiências é assunto que, embora não totalmente esclarecido em alguns casos, é bem conhecido de uma forma geral, distinguindo-se, por uma questão de sistematização, uma deficiência primária e uma deficiência secundária.

Refere-se or deficiência primária a que resulta da presença de te is do elemento insuficientes em relação às necessidades da dieta alimentar corrente do animal (ou planta) considerado. Normalmente, para as plantas e animais que delas se alimentam exclusivamente, a origem da deficiência está na composição geoquímica dos solos, a qual pode ser tal que o elemento esteja presente em teores muito baixos, ou que esteja presente em formas pouco acessíveis, por si próprias ou devido à presença de outros elementos ou compostos. Um exemplo deste último caso é o do ferro em solos calcários, de $\mathrm{pH}$ Quadro VI

Doenças e perturbaçסes resultantes da deficiência ou do excesso de elementos essenciais

\begin{tabular}{lcc}
\hline \multirow{2}{*}{ Elemento } & \multicolumn{2}{c}{ Doença ou perturbação } \\
\cline { 2 - 3 } Cálcio & $\begin{array}{l}\text { Enfraquecimento dos os- } \\
\text { sos, excitabilidade neu- } \\
\text { romuscular, tetania }\end{array}$ & $\begin{array}{l}\text { Espessamento dos ossos e } \\
\text { calcificação de cartilagens. } \\
\text { Cálculos urinários, para- } \\
\text { das cardiacas }\end{array}$ \\
Cobalto & Anemia perniciosa, ano- & Cardiomiopatia, anore-
\end{tabular}
rexia, degenerescência da medula espinal

Cobre Anemia, ataxia (em carneiros), queratinização deficiente, pigmentação deficiente

xia, policitemia

Doença de Wilson, necrose hepática, cirrose, crises hemoliticas

Crómio Metabolismo da glucose anormal, diabetes (?), opacidade da córnea

Flúor Cárie dental, mortalidade perinatal

Ferro Anemia

Iodo Bócio, deficiências reprodutoras, queda de cabelo e do pelo

Magnésio Hiperirritabilidade neuro-muscular, tetania, acidentes cárdio-vasculares (morte-repentina)?

Manganês Deformaçōes ósseas, infertilidade, ataxia

Molibdénio Queratinização defeituosa

Niquel Mortalidade perinatal

Selénio Necrose hepática, distrofia mucular (white muscle disease), infertilidade, lesőes de tecidos, artrite crónica, queda de cabelo

Silicio

Deformaçōes ósseas, defeitos nas cartilagens, incidîncia de doenças cárdio vasculares (?)

Zinco

Anorexia, enfesamento, paraqueratose, alopécia, hipogonadismo, dificuldades de cicatrização tremores

Disenteria persistente (gado)

Diarréia, anestesia, depressão do sistema nervoso central e periférico

Dermatites de contacto, carcinoma de pulmão

Cambaleio cego («blind-staggers") e doença alcalina (gado)

Silicose

Febre dos fumos metáli$\cos$ (febre, tremores) 
elevado, que precipita na forma de hidróxido e se torna pouco acessivel às plantas ( $\mathrm{e}$ aos animais que delas se alimentam).

Por deficiência secundária refere-se a que deriva da utilização sub-óptima dos elementos essenciais, mesmo que eles estejam presentes em quantidade suficiente na dieta alimentar. Este tipo de deficiência pode ocorrer por diversas razð̃es, das quais as mais importantes serão, provavelmente, as seguintes:

1. Interacção entre o elemento considerado e antagonistas presentes na dieta, que impeçam a absorpção do primeiro ou alterem o seu processo de incorporação nas respectivas sedes funcionais.

2. Defeitos genéticos que afectem o metabolismo dos elementos essenciais, modificando, por exemplo, os grupos receptores das proteinas ou ligandos envolvidos na captação, transporte ou armazenamento desses elementos.
Em relação à deficiência primária pouco haverá a acrescentar ao que já foi dito; como é evidente, os problemas da deficiência primária serão menores para o homem citadino, cuja dieta alimentar é variada e de origens diversas, embora o excessivo consumo de alimentos enlatados ou excessivamente processados possa também ocasionar a diminuição do teor de alguns elementos essenciais abaixo dos limites desejáveis e provocar, do mesmo modo, efeitos de deficiência. Assim, a dieta alimentar média do cidadão de países evoluídos, como os E.U.A. e a Inglaterra, parece ser deficiente em diversos alimentos essenciais $\left({ }^{16}\right)$; naturalmente, noutras regiðes do globo (e não só nas subdesenvolvidas) serão igualmente de esperar problemas associados à carência de elementos minerais.

No Quadro VII apresenta-se um resumo contendo as fontes habituais dos elementos químicos essenciais para o homem, dos teores totais no organismo, dos requisitos diários, dos valores médios das dietas alimentares e da percentagem de absorpção provável das fontes.

Quadro VII

Elementos essenciais - Fontes mais importantes, teor total no homem adulto, requisitos diários, ingestão diária média e percentagem de absorção (valores aproximados em $\mathrm{mg}$ )

\begin{tabular}{|c|c|c|c|c|c|}
\hline Elemento & Teor total no homem & Requisitos diários & Ingestão diária média & \% de absorpção & Fontes mais importantes \\
\hline Cálcio & 1000000 & 500 & 1500 & 30 & Leite, lacticínios, hortaliças, moluscos \\
\hline Magnésio & 19000 & 300 & 300 & 35 & Vegetais (clorofila) \\
\hline Silício & 18000 & 3 & 20 & 1 & Fibras cereais, vegetais, águas \\
\hline Ferro & 4200 & $1-2$ & 15 & 10 & Carne, peixe, aves, feijão, ervilha, agrião \\
\hline Flúor & 2600 & 1 & 0,3 & 85 & Chá, peixe (do mar), águas fluoretadas \\
\hline Zinco & 2300 & 3 & 13 & 40 & $\begin{array}{l}\text { Ostras, germen de trigo, ovos, cereais, } \\
\text { sementes de leguminosas }\end{array}$ \\
\hline Cobre & 120 & 2 & 5 & 35 & $\begin{array}{l}\text { Crustáceos, ostras, figado, rins, nozes, } \\
\text { legumes secos }\end{array}$ \\
\hline Vanádio & 25 & 0,003 & 2 & 5 & $\begin{array}{l}\text { Oleos e gorduras vegetais (soja, azeite); } \\
\text { gorduras animais }\end{array}$ \\
\hline Iodo & 20 & 0,2 & 0,2 & 100 & Sal de mesa, peixe (do mar), marisco \\
\hline Selénio & 20 & $?$ & 0,1 & 60 & $\begin{array}{l}\text { Figado, rins, farinha de peixe, certas } \\
\text { plantas }\end{array}$ \\
\hline Manganês & 15 & 2,5 & 4 & 3 & $\begin{array}{l}\text { Nozes, cereais, sementes leguminosas, } \\
\text { frutos secos }\end{array}$ \\
\hline Molibdénio & 9 & 0,1 . & 0,2 & 50 & Legumes, cereais, figado, rim \\
\hline Crómio & 6 & 0,2 & 0,1 & 10 & $\begin{array}{l}\text { Carne, cerveja, farinha de trigo (não } \\
\text { refinada) }\end{array}$ \\
\hline Cobalto & 2 & 0,00004 & 0,3 & 80 & $\begin{array}{l}\text { Carne, lacticínios, vegetais (espinafre), } \\
\text { ovos, ostras, ameijoas }\end{array}$ \\
\hline
\end{tabular}

Fontes: R. Masironi: La Tribune du Cebedeau, 419, 363 (1978); E. J. Underwood: Trace elements in human and animal nutrition, Academic Press, 1977.

Tendo em conta os valores apresentados é possível elaborar nova tabela - Quadro VIII - onde se apresentam, para o homem adulto, os desequilíbrios possíveis ou suprimento de elementos químicos essenciais derivados da sua dieta alimentar em condiç̃̃es normais, mas atendendo também a alguns efeitos de deficiência secundária (ver Quadro IX).

Deve dizer-se, em relação a este Quadro, que mesmo nos casos de deficiências improváveis se têm registado numerosos exemplos de ocorrência bem documentados. Adiante retomaremos este aspecto.

Os problemas de deficiência primária poderão ser ampliados ou reproduzidos por efeitos não directamente ligados à abundância, que já referimos como de deficiência secundária.

$\mathrm{Na}$ verdade, pode acontecer, e esse é o caso normal, que a dieta alimentar contenha outras espécies - elementos essenciais ou não e compostos orgânicos de diversa natureza - que interfiram com a absorpção ou utilização normal do elemento em causa e que, de um modo geral, designaremos por antagonistas.

O efeito dos antagonistas será o de aumentar os requisitos por esses elementos ou, como adiante se verá na análise de alguns casos, o de fazer variar a tolerância a certos elementos tóxicos (provocando o aparecimento de sintomas que não derivam propriamente de deficiência e sim de excesso).

No Quadro IX apresenta-se um conjunto de antagonistas para diversos elementos essenciais, incluindo na definição aqueles elementos, essenciais ou não, que competem com um determinado elemento essencial pelas suas sedes de ligação ou coordenação, em termos de equilíbrio múltiplo.

Os casos de antagonismo mais estudados são, provavelmente o do cobre-molibdénio e o da interacção 
Quadro VIII

Desiquilibrio de elementos essenciais no homem adulto (+ : possível; - : improvável)

\begin{tabular}{|c|c|c|}
\hline Elemento & Deficiência & Excesso - observaçōes \\
\hline Cálcio & + & + \\
\hline Magnésio & + & - \\
\hline Zinco & + & - \\
\hline Crómio & + & - \\
\hline Selénio & + & $-\cdot$ \\
\hline Ferro & + & $+\quad$ (utensílios de ferro) \\
\hline Iodo & + & $+\quad$ (alimentos e medicamentos \\
\hline Flúor & + & (águas fluoretadas) \\
\hline Vanádio & - & 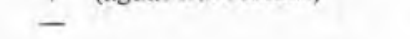 \\
\hline Silício & - & - \\
\hline Cobre & - & - \\
\hline Manganês(*) & - & - \\
\hline Molibdénio & - & (solos ricos em Mo-URSS) \\
\hline Cobalto & - & 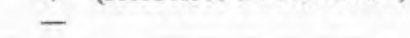 \\
\hline
\end{tabular}

Fonte: R. Masironi: La Tribune du Cebedeau, 419, 363(1978).

(*) A ocorrência de deficiência de manganês é possível, mas o seu papel poderá, até certo ponto e em alguns casos, ser suprido pela presença de magnésio.

do cálcio, magnésio, zinco, cobre, manganês e outros iðes com o ácido fítico (hexafosfato de inositol) presente nos alimentos à base de cereais e de proteínas vegetais.

$\mathrm{O}$ antagonismo cobre-molibdénio (ao que parece, associado à presença de sulfato) é provavelmente a razão principal da existência de deficiências nutritivas em cobre no gado ruminante $\left({ }^{17}\right)$. Quantidades de molibdénio da ordem dos 5 p.p.m. podem impedir até $75 \%$ da absorpção do cobre da dieta alimentar e o processo é estimulado pela presença de compostos sulfurados $\left({ }^{25}\right.$ ) (que podem ser oxidados a sulfato?). Uma doença óssea («genu valgum») que se tem generalizado na Índia Oriental e que atinge já 1 milhão de indivíduos, pode resultar deste impedimento de absorpção do cobre devido à presença de molibdénio, mas a incidência de fluorose na região, proveniente do excesso de flúor, pode não ser alheia ao problema $\left({ }^{25,26}\right)$.

O mecanismo deste efeito não está esclarecido, mas sabe-se que os tio - ou oxi-tiomolibdatos restringem a absorpção do cobre através da mucosa intestinal talvez por formação de um composto pouco solúvel com o

\section{Quadro IX}

Componentes da dieta alimentar que se comportam como antagonistas, aumentando os requisitos de elementos essenciais ou diminuindo a tolerância a elementos tóxicos

\begin{tabular}{|c|c|}
\hline Elemento & Antagonistas \\
\hline Cobalto & Nenhum conhecido \\
\hline Cobre & Molibdénio, compostos sulfurados, fitato, $\mathrm{Zn}, \mathrm{Cd}$ \\
\hline Crómio & Relação $\mathrm{VO}^{3-} / \mathrm{CrO}^{2-}$ \\
\hline Flúor & Cálcio, alumínio \\
\hline Ferro & Cálcio, $\mathrm{PO}^{3-}, \mathrm{CO}^{2-}, \mathrm{OH}^{*}, \mathrm{Cu}, \mathrm{Zn}, \mathrm{Mn}, \mathrm{Cd}, \mathrm{Co}$, fitato \\
\hline Iodo & Tio-oxalidonas, $\mathrm{SCN}^{-}, \mathrm{ClO}_{4}, \mathrm{Co},(\mathrm{As}),(\mathrm{F})$ \\
\hline Manganês & Fitato, $\mathrm{PO}^{3-}, \mathrm{Ca}$ \\
\hline Molibdénio & $\mathrm{SO}^{2-}, \mathrm{PO}^{3-}$, relação $\mathrm{WO}^{3-} / \mathrm{MoO}^{3-}$ \\
\hline Selénio & $\begin{array}{l}\mathrm{Cu},(\mathrm{As}),(\mathrm{Hg}), \mathrm{SO}^{4-} \text { e outros compostos de enxofre aná- } \\
\text { logos aos de selénio }\end{array}$ \\
\hline Silicio & Nenhum conhecido \\
\hline Vanádio & $\mathrm{Nb}$, relação $\mathrm{CrO}^{2-} / \mathrm{VO}^{2-}$ \\
\hline Zinco & Fitato, $\mathrm{Ca}, \mathrm{Cu},(\mathrm{Cd})$ \\
\hline
\end{tabular}

Fonte: C. F. Mills: Chem. Brit. 15, 512 (1979). cobre $\left({ }^{18}\right)$. Por outro lado, quando absorvidos, os mesmos compostos de molibdénio aumentam a afinidade das proteínas do plasma e dos rins pelo cobre, impedindo a sua utilização por outros tecidos $\left({ }^{25}\right)$, mas não é fácil prever qual o mecanismo operante neste processo.

Dado que o molibdénio em biologia está envolvido numa sé ie de sistemas todos de potencial redox baixo $\left.{ }^{19}\right)$, não é impossível que, «in vivo» a acção antagonista em relação ao cobre se exerça por redução deste elemento ao estado cuproso ou do sulfato a sulfureto, precipitando sulfureto de cobre; assim a função oxidase de algumas enzimas poderá ser inibida originando manifestações de deficiência, mas estas hipóteses terão de ser consideradas como especulativas até se obter alguma evidência experimental deste efeito.

O segundo tipo de antagonismo que referimos é mais simples de interpretar: deve-se à formação de derivados estáveis e insolúveis de muitos ið̋es metálicos com o ácido fítico, importante reserva de fósforo existente nos grãos de cereais, como a aveia, e noutros tecidos das plantas. O consumo crescente de proteínas vegetais, frequentemente ricas em fitato, como substitutivos da carne, é susceptível de aumentar as deficiências naqueles elementos cuja absorpção é dificultada.

$\mathrm{O}$ caso do zinco é particularmente agudo pois a carência deste elemento provoca, a muito curto prazo, perturbaçðes de crescimento. Por outro lado, o zinco participa na enzima intestinal fitase, que degrada o ácido fítico e impede o seu efeito, pelo que o processo de inibição aumenta exponencialmente, tanto em relação a este elemento como a outros que formam também compostos pouco solúveis com o ácido fítico.

É o caso do ferro e também do cálcio e do magnésio, em relação aos quais podem ocorrer sintomas de deficiência embora estejam presentes em teor elevado nos alimentos consumidos (recordar a ocorrência de raquitismo em populaçōes alimentadas à base de farinhas de cereais)

Um antagonismo de tipo semelhante poderá ser ocasionado pela presença na dieta alimentar de aminoácidos e proteínas que possam complexar os iðes dos elementos essenciais. Há casos relatados na literatura sobre a indução acidental de deficiências de zinco e cobre em pessoas mantidas sob regime alimentar intravenoso ou intragástrico à base de proteinas purificadas $\left({ }^{20}\right)$.

Ainda dentro do mesmo tipo de antagonismo podem incluir-se os casos de inibição competitiva, que resultam da possibilidade de iס̃es de elementos diferentes competirem entre si pelas mesmas sedes coordenativas dos ligandos biológicos usados para captura, transporte, armazenamento ou funcionamento de um elemento determinado. Neste caso, a correspondência de configuração electrónica, a semelhança de raios iónicos, a analogia estrutural das espécies, bem como as suas concentraçōes relativas serão factores determinantes do maior ou menor grau de interacção $\left(^{1,21}\right)$ e o número de exemplos que se podem citar é bastante extenso (veja-se o Quadro IX, que resume muitos dos dados disponíveis sobre o problema). Em certos casos o antagonismo pode não resultar de competição directa; por exemplo, o zinco é antagonista do ferro por afectar a incorporação deste elemento na transferrina e diminuir a vida dos eritrócitos, aumentando indirectamente os requisitos diários do mesmo $\left({ }^{25}\right)$. 
Poderão ainda dar-se fenómenos secundários menos directamente correlacionáveis com a competição referida. Um exemplo elucidativo é o da resposta do organismo a excessos de cádmio, que estimula a sintese em certos tecidos (mucosa intestinal, fígado, rins) de uma proteína com grupos tiólicos (metalotionina) capaz de sequestrar este elemento e impedir os seus efeitos tóxicos $\left({ }^{22}\right)$. Todavia, esta proteína não é específica e pode complexar também o cobre e o zinco $\left({ }^{23}\right)$, pelo que a sua presença pode alterar o metabolismo normal destes elementos e levar a sintomas característicos da sua deficiência. Como consequência, carências pré-existentes de, por exemplo, cobre, aumentam os riscos da toxicidade do cádmio, baixando os limites a partir dos quais a ingestão deste causa perturbaçōes metabólicas $\left({ }^{24,}\right.$ ${ }^{25}$ ). Tal como neste caso, a deficiência de ferro diminui a tolerância ao cádmio e ao chumbo e a deficiência de zinco ou de selénio diminui a resistência a intoxicação por chumbo $\left({ }^{25}\right)$.

Embora não existam explicações detalhadas para estas interacçð̃es, não se deve esquecer que o metabolismo de todos os metais está intimamente associado no organismo e que não há mecanismos inteiramente independentes; nestas condiçōes o desequilíbrio no estado de disponibilidade de um deles forçosamente se repercutirá, em maior ou menor grau, nos efeitos de deficiência ou de excesso de todos os outros, essenciais ou não essenciais, que compitam com eles. Um aspecto diferente desta interrelação é o da elevação do teor de cobre e concomitante diminuição dos teores de ferro e zinco no soro sanguineo que ocorre durante os estados infecciosos, sendo esta redistribuição iniciada por um factor segregado por células fagocíticas $\left({ }^{27}\right)$. Trata-se obviamente de um mecanismo de defesa adicional, bem ilustrativo da essencialidade destes elementos para os próprios agentes infecciosos.

Uma segunda razão para a ocorrência de deficiências secundárias é, como se disse, consequência de defeitos genéticos que levem a alterações na estrutura de grupos receptores dos ligandos biológicos envolvidos no metabolismo dos elementos essenciais. Exemplos conhecidos são o da doença «acrodermatite enteropática” $\left({ }^{28}\right)$ (deficiência de zinco) e o da doença de Menkes em crianças $\left({ }^{20}\right)$ (deficiência de cobre).

Noutros casos, a existência de defeitos genéticos poderá levar não a doenças de deficiência mas a doenças resultantes de excesso, como é o caso da doença de Wilson $\left({ }^{29}\right.$ ) (excesso de cobre, acumulado no figado, rins e cérebro). Não nos alongaremos sobre este aspecto que sai um pouco fora do âmbito do presente trabalho, a não ser para salientar que o conhecimento correcto das sedes funcionais naturais de cada elemento poderá levar à sintese de ligandos que permitam melhores processos de quimioterapia, e o caso desta última doença é um excelente exemplo: complexantes com um grupo coordenante igual ao da albumina transportadora de cobre foram sintetizados e poderão ser utilizados com êxito no tratamento da mesma $\left({ }^{29,30}\right)$.

\section{Relações causa-efeito}

Como antes se referiu, um dos aspectos cujo conhecimento se torna particularmente importante é o do mecanismo através do qual a deficiência de um elemento essencial (ou o seu excesso) se repercute no aparecimento de determinadas perturbaçð̃es ou doenças e a velocidade com que tal ocorre.

O conhecimento destas relaçð̃es é importante sob o ponto de vista clínico, pois pode permitir intervir a tempo de evitar lesões muitas vezes irreversiveis; também sob o ponto de vista económico, a possibilidade de uma intervenção preventiva ou correctiva de doenças do gado, por exemplo, é um aspecto que não deve ser negligenciado.

A interrelação de processos torna, todavia, difícil o estabelecimento de relações directas causa-efeito; vimos anteriormente casos em que a deficiência de um elemento pode ocasionar perturbaçōes associadas com a deficiência de outro. A anemia, por exemplo, que é um estado de deficiência de hemoglobina, pode resultar não directamente da deficiência de ferro mas sim das deficiências de zinco ou cobre (que parecem assistir ao processo de incorporação do ferro na transferrina e no heme) ou da deficiência de cobaito (associado ao processo de hematopoiese). Casos existem também em que a deficiência de um elemento leva à sua substituição por outro; é possível, por exemplo, que a deficiência de zinco origine a substituição deste elemento por manganês ou magnésio na RNA-polimerase, o que leva à produção de RNA anómalo e à síntese de proteínas alteradas, podendo este facto estar na base dos efeitos teratogénicos registados em casos da referida deficiência $\left({ }^{31,32}\right)$.

Por outro lado, o papel de cada elemento essencial não é específico, na maioria dos casos, pelo que a sua deficiência se repercute numa variedade de processos bioquímicos de forma não simultânea nem regular, as quais poderão dar lugar a diferentes tipos de perturbaçōes.

Como é evidente, nesta questão haverá que considerar vários aspectos: o da extensão das reservas dos elementos considerados, o da maior ou menor facilidade de mobilização dessas reservas, o da ocupação relativa de cada sede funcional pelo elemento considerado e por outros elementos, função da afinidade por essa sede e das concentraçōes respectivas, e o da velocidade com que a desregulação de um determinado mecanismo bioquímico se traduz em sintomas observáveis.

Por outro lado há que atender a que estes aspectos não são uniformes e variam com a espécie animal considerada e seu estado de desenvolvimento; por exemplo, o cobre é armazenado no fígado de ruminantes, porcos e aves, mas não no fígado do homem, e as reservas de animais novos podem ser consideravelmente menores que as dos adultos.

Em alguns casos parecem não existir formas de armazenamento facilmente mobilizáveis e será de esperar uma resposta fisiológica mais rápida aos estados de deficiência. O zinco parece estar nessas condiçōes e a sua deficiência na dieta alimentar acarreta a curto prazo sintomas como a perda de apetite e a diminuição do ritmo de crescimento (diminuição da actividade dos enzimas digestivos), que precedem o aparecimento de lesð̄es da pele e dos ossos, estas devidas talvez a mobilização posterior dos depósitos de zinco correspondentes.

Em contraste com esta situação, as deficiências de cobre, selénio ou de outros elementos só vêm a traduzirse em manifestaçōes patológicas após um periodo relativamente mais longo, precedido por uma série de alterações de mecanismos bioquímicos nem sempre directamente relacionáveis com a defiçiência específica de um dado elemento.

Caberá notar que embora os efeitos de deficiência dos vários elementos essenciais tenham sido observados e estudados em diversos animais, o número de casos para 
os quais se registam deficiências no homem é bem mais reduzido. Os casos mais documentados são os do cálcio, ferro, cobre, zinco, cobalto (como vitamina $\mathrm{B}_{12}$ ) e iodo; outros elementos para os quais existem observaçōes menos detalhadas ou até ocasionais são os do manganês $\left({ }^{33}\right)$, magnésio $\left({ }^{34}\right)$ e silício $\left({ }^{35}\right)$. Consequências de eventuais deficiências de selénio, molibdénio e níquel não foram ainda observadas em seres humanos e o flúor, embora seja preventivo da cárie dentária, não tem a sua essencialidade provada para o homem.

Quanto ao crómio e ao vanádio, observaçōes recentes permitem prever um papel importante para o primeiro na regulação do metabolismo da glucose $\left({ }^{36}\right) \mathrm{e}$, para o segundo, uma função reguladora da $\mathrm{Na}+\mathrm{K}$ - ATPase e da $\mathrm{Ca}$ - ATPase ainda mal conhecida $\left({ }^{37},{ }^{38}\right)$, mas não se poderá falar propriamente de efeitos de deficiência já observados.

No Quadro X resumimos algumas alteraç̃es observadas no homem a nível dos mecanismos bioquímicos e as perturbações ou doenças que podem associar-se a essas alterações, umas mais directamente e outras de modo mais indirecto. Uma discussão pormenorizada destas relações está fora das possibilidades e intenções do presente trabalho, mas não é difícil deduzir a partir dos dados do Quadro e das observações feitas sobre a maior ou menor facilidade de mobilização dos depósitos, qual a ordem de aparecimento dos sintomas de deficiência de cada um dos elementos considerados. Desejável será poder-se identificar o mais cedo possível os primeiros desses sintomas característicos, confirmar por análise a origem dos mesmos e intervir a tempo de corrigir os efeitos.

Em muitos casos esta intervenção é simples, bastando a simples suplementação da dieta alimentar para eliminar totalmente as perturbaçð̄es verificadas; noutros, porém a situação pode ser irreversível (como no caso da «doença de Menkes»), pelo que a conveniência de um diagnóstico tão oportuno quanto possível ou até de trabalhos de análise com fins preventivos ressalta evidente.

A dificuldade está no reconhecimento dos sintomas e na identificação segura da deficiência; que tipo de análise e quais os testes que podem considerar-se decisivos? Embora se tenha feito um progresso considerável em anos recentes não se chegou ainda a um esquema de detecção de deficiências dos vários elementos essenciais simultaneamente simples e incontroverso.

\section{Conclusão}

A simples enumeração dos aspectos envolvidos e das dificuldades associadas à interpretação dos fenómenos observados indica o caminho a percorrer até se estabelecer algo semelhante a um desejável modelo nutricional-bioquímico-fisiológico de um animal, projecto extremamente complexo e ambicioso mas talvez não impossível, pelo menos nas suas grandes linhas.

Do ponto de vista dos químicos inorgânicos existem tarefas particularmente importantes a realizar nesse sentido: a determinação mais precisa da distribuição dos elementos pelos diferentes tecidos e compostos funcionais, o esclarecimento do modo como esses elementos se ligam a esses compostos, a determinação das constantes de estabilidade das espécies formadas, o estudo da cinética das reacçð̃es da mobilização dos seus

Quadro X

Algumas possíveis correlaçð̃es entre alteraçōes metaboblicas observadas e anomalias fisiológicas em animais

\begin{tabular}{lll}
\hline $\begin{array}{l}\text { Elemento } \\
\text { deficiente }\end{array}$ & \multicolumn{1}{c}{$\begin{array}{c}\text { Alteraçð̃es } \\
\text { metabólicas }\end{array}$} & \multicolumn{1}{c}{$\begin{array}{c}\text { Anomalias } \\
\text { fisiologicas }\end{array}$} \\
\hline & $\begin{array}{l}\text { Ceruplasmina: redução } \\
\text { do nivel plasmático }\end{array}$ & $\begin{array}{l}\text { Anemia (deficiente incor- } \\
\text { poração do ferro na trans- } \\
\text { ferrina e/ou nos rectículo- } \\
\text { citos }\end{array}$ \\
\hline Tirosinase: Actividade & Despigmentação, albinis-
\end{tabular}

Tirosinase: Actividade reduzida

Cobre

Lisina-oxidase: actividade reduzida

Citocromo-oxidase: actividade reduzida

Deficiência de vitamina $B_{12}$

Metilmalonil - CoA isomerase: actividade dimi-

Cobalto nuida

Excreção de ácido formininoglutâmico aumentada (inibição da produção te ácido tetrahidrofolico?)

Factor de tolerância da glucose reduzido

Diminuição de crescimento e da longevidade;

Crómio

Hiperglicemia e glicosúria Opacidade da córnea (primatas); diabetes (?)

\begin{tabular}{lll}
\hline Ferro & $\begin{array}{l}\text { Diminuição da taxa de } \\
\text { sintese de hemoglobina }\end{array}$ & Anemia \\
\hline Iodo & $\begin{array}{l}\text { Diminuição do teor de } \\
\text { hormonas da tiróide }\end{array}$ & \\
\hline
\end{tabular}

Provável aumento de cálcio intracelular:

Magnésio

Inibição de Ca-ATPase?

Diminuição da actividade da adenilato ciclase e da sintese de AMP?

Glicosil-transferrases: actividade reduzida - diminuição da sintese de mucopolisacarídeos e glicoproteinas

Manganês
Espasmos da coronária aumento da tensão arterial, acidentes cardíacos (doença da «morte repentina»?

Inibição da coagulação sanguínea (deficiência da protrombina-glicoproteina)

Redução do nível de colesterol no sangue (deficiência da sintese de esteroides)

Ataxia (deficiência da síntese de mucopolisacarideos dos otolitos)

Retardamento do crescimento, defeitos de formação de cascas de ovos, deformaçőes ósseas, etc. 


\section{Glutationa-peroxidase (fi gado, músculos, plasma, globulos vermelhos): acti- vidade reduzida \\ Selénio}

Seleno-proteína dos músculos: ausência nos animais com degenerescência muscular

Silício Não identificadas $\quad \begin{aligned} & \text { Aumento de acidentes cár- } \\ & \text { dio-vasculares? }\end{aligned}$

Aumento do nível de colesterol no sangue? Deficiência de "cross-linking" nos tecidos dos vasos circulatórios?

\begin{tabular}{|c|c|c|}
\hline Vanádio & Não identificados & $\begin{array}{l}\text { Retardamento do cresci- } \\
\text { mento }\end{array}$ \\
\hline \multirow[t]{8}{*}{ Zinco } & $\begin{array}{l}\text { Carboxipeptidase: activi- } \\
\text { dade reduzida }\end{array}$ & $\begin{array}{l}\text { Deficiências de amino- } \\
\text {-ácidos para nutrição }\end{array}$ \\
\hline & $\begin{array}{l}\text { Alcalino-fosfatase: acti- } \\
\text { vidade reduzida }\end{array}$ & Deficiências ósseas \\
\hline & $\begin{array}{l}\text { Álcool-desidrogenase: } \\
\text { actividade reduzida }\end{array}$ & $\begin{array}{l}\text { Cirrose hepática (cone- } \\
\text { xðes) }\end{array}$ \\
\hline & $\begin{array}{l}\text { Leucina-aminopeptidase: } \\
\text { actividade reduzida }\end{array}$ & $\begin{array}{l}\text { Paraqueratose, atrofia tes- } \\
\text { ticular }\end{array}$ \\
\hline & $\begin{array}{l}\text { Timidina-quinase: activi- } \\
\text { dade reduzida }\end{array}$ & \\
\hline & $\begin{array}{l}\text { Lactato e malato-desidro- } \\
\text { genases: actividade redu- } \\
\text { zida }\end{array}$ & \\
\hline & $\begin{array}{l}\text { ¿-aminolevulinato-desi- } \\
\text { dratase: actividade redu- } \\
\text { zida }\end{array}$ & Anemia \\
\hline & $\begin{array}{l}\text { RNA e DNA - polime- } \\
\text { rases(?): actividade redu- } \\
\text { zida }\end{array}$ & $\begin{array}{l}\text { Retardamento do cresci- } \\
\text { mento } \\
\text { Defeitos teratogénicos }\end{array}$ \\
\hline
\end{tabular}

diferentes depósitos ou das reacçð̃es de competição dos vários elementos essenciais e não essenciais pelos mesmos ligandos biológicos.

Essa será a base da informação mínima que permitirá racionalizar muitas das observaçð̄es registadas na literatura.

Aos bioquímicos caberá aprofundar o estudo dos mecanismos biológicos em que participam directa ou indirectamente os elementos essenciais, bem como das interligaçðes sobre esses mecanismos, de modo a se poder conhecer exactamente o modo como um determinado sistema reage à diminuição da concentração de um elemento determinado ao longo de um certo período.

Aos fisiologistas caberá, enfim, estabelecer em bases mais sólidas a ligação entre as alteraçð̃es registadas ao nível dos mecanismos bioquímicos e a ocorrência de perturçðes, lesð̌es ou doenças, provenientes, em última análise, da deficiência ou do excesso de um elemento essencial ou, talvez melhor, do desequilíbrio na concentração dos elementos essenciais provocados pela variação de algum ou alguns deles (ou pela presença de elementos estranhos).
É um programa para muitas dezenas de anos, mas a importância dos objectivos dá o necessário encorajamento para o prosseguimento dos trabalhos, que, em poucos decénios, forneceram muitos resultados animadores, por vezes espectaculares, e em muitos casos imediatamente úteis.

\section{REFERENCIAS}

(1) J.J.R. Fraústo da Silva e R.J.P. Williams: Structure and Bonding 29, 67 (1976)

(2) I. Fridovich: Science, 201, 875 (1978)

(3) K. Schwarz: Fed. Proc. 33 (6), 1748 (1974)

(4) R.J.P. Williams: Chem. in Britain, 15, 506 (1979)

(5) M.J. Bowen: Trace elements in biochemistry, Academic Press, Londres, 1966

(6) J.J.R. Fraústo da Silva in «New trends in bioinorganic Chemistry", ed. R.J.P. Williams e J.J.R. Fraústo da Silva, Academic Press, Londres, 1978, pg. 449

(7) W. Forth e W. Rummel: Physiol. Rev. 53, 724 (1973)

(8) R.R. Crichton: Angew, Chem. Int. Ed, 12, 57 (1973)

(9) F.M. Bockxmeer e E.H. Morgan: Biochem. Biophys. Acta 468, 437 (1977)

(10) E.J. Zapolski e J.V. Princiotto: Biochem. Biophys. Acta. 428, $766(1976)$

(11) J. Mazurier e G. Spik: Biochem. Biophys. Acta 629, 399 (1980), para referências

(12) D. Drescher e H.F. De Luca: Biochemistry 10, 2302, 2308 (1971)

(13) G. Nicholls e R.H. Wasserman, eds.: Celular Mechanisms for Calcium transfer and homeostasis, Academic Press, N.Y. 1971

(14) E. Carlisle: Fed. Proc. 34 (3), 927 (1975)

(15) F.G.E. Pautard in "New trends in bioinorganic chemistry", ed. R.J.P. Williams e J.J.R. Fraústo da Silva, Academic Press, Londres, 1978, pg. 261

(16) World Health Organization: Trace elements in human nutrition, Tech. Rept. n. ${ }^{\circ} 532$, Genebra, WHO, 1973

(17) E.J. Underwood: Trace elements in human and mineral nutrition, 4. ${ }^{2}$ edição, Academic Presș, N.Y., 1977, pg. 97 e 132 e referências indicadas

(18) N.J. Clarke e L.G,H. Tipping: Jouvn. Inorg. Biochem. 12, 37 (1980)

(19) R.J.P. Williams e J.J.R. Fraústo da Silva in «New trends in bioinorganic chemistry, ed. R.J.P. Williams e J.J.R. Fraústo da Silva, Academic Press, Londres, 1978, pg. 121

(20) K.M. Hambidge: Proc. Nutr. Soc. 33, 307 (1974)

(21) C.H. Hill e G. Matrone: Fed. Proc. 29, 1474 (1970)

(22) Y. Kojima e J.H.R. Kagi: Trends biochem. Sci. 3, 90 (1978)

(23) K. Lerch: Nature, 284, 368 (1979)

(24) I. Bremmer: Quart. Rev. Biophys. 7, 75 (1974)

(25) C.F. Mills: Chemistry in Britain 15, 512 (1979), referências e discussão geral dos problemas de deficiência e excesso de elementos-traço

(26) K.A.V.R. Krishnamachari e K. Krishnaswamy: Ind. J. med. Res. 62, 1415 (1974)

(27) W.R. Beisel, R.S. Pekarek e R.W. Wannemacher, Jr., in «Trace elements in animal metabolism-2, ed. W. Hoekstra e outros, University Park Press, Baltimore, Maryland, 1974, pg. 218

(28) E.J. Moynaham e P.M. Barnes: Lancet 2, 399 (1974)

(29) B. Sarkar in "An Introduction to bio-inorganic chemistry", ed. D.R. Williams, Charles C. Thomas Publs., Springfield, Ill., 1976, pg. 318

(30) B. Sarkar in Jerusalém Symp. Quantum Chemistry, Biochem., pgs. 193-228 (1977)

(317 S. Ochoa e R. Mazuner in "The enzymes", ed. P.D. Boyer, vol. 10, pg. 1, Academic Press, N. York, 1974

(32) W.P. Tate e C.T. Caskey in "The enzymes", ed. P.O. Boyer, vol. 10, pg. 87, Academic Press, N. York, 1974

(33) E.A. Doisy (1972), Y. Tanaka (1978), observaçðes clinicas referidas em H.J. Sanders: Chem. Eng. News, Março 26, (1979) pg. 27

(34) P.D.M.V. Turlapaty e B.M. Altura: Science, 208, 198 (1980)

(35) K. Schwarz et. al.: The Lancey, 454, 538 (1977)

(36) W. Mertz: Trace subst. Environ. Helth 11, 167 (1977)

(37) T.J.B. Simons: Nature 281, 337 (1979) e referências indicadas neste artigo

(38) I.G. Macara, K. Kustin, L.C. Cantley: Biochem. Biophys. Acta $629,95(1980)$ 